BIOKEMISTRI 16(2):94-101 (December 2004)

Printed in Nigeria

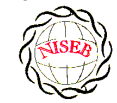

OVigerian Society for \&̊xperimental Siology

\title{
Toxicological evaluation of the surface water of Amilegbe River using rats
}

\author{
Adenike T. OLADIJI*, Olalekan ADEYEMI and Oladunni O. ABIOLA \\ Department of Biochemistry, University of Ilorin, PMB 1515, Morin, Nigeria.
}

Received 10 May 2004

\begin{abstract}
Samples of water from Amilegbe River were collected for the determination of physicochemical characteristics and were fed to rats over a period of eight weeks. Total solids, total dissolved solids, biochemical oxygen demand and chemical oxygen demand values were higher in Amilegbe river water than both bore-hole water and WHO standards. Packed cell volume, red blood count, hemoglobin concentration were significantly lower in test group than those of control group $(\mathrm{p}<0.05)$. In contrast, body weight, neutrophils, white blood count and platelet concentrations increased significantly in test group compared with those of control group $(\mathrm{p}<0.05)$. Activities of all the enzymes studied reduced significantly in the kidney, small intestine and liver of test rats compared with the control $(\mathrm{p}<0.05)$. However, serum enzyme activities, with the exception of serum ALP, increased significantly in test group compared with the control $(\mathrm{p}<0.05)$. It may be considered that Amilegbe river water is indeed polluted and its consumption may cause leakage of enzymes such as AST and ALT from tissues to the serum thereby leading to various disease conditions
\end{abstract}

Key words: River water, bore-hole water, physicochemical changes, marker enzymes, rats

*Author to whom correspondence should be addressed.

E-mail: atoladiji@yahoo.com Tel: 08033736996 


\section{INTRODUCTION}

Surface-water is a term used to describe water sources occurring naturally on the ground (1). This includes oceans, rivers, streams and lakes. Surface waters serve as source of water to some people in the developing countries (2). However, surface-waters in developing countries such as Nigeria are predisposed to pollution (1). High population and indiscriminate waste disposal promote pollution of these water bodies (3).

Pollution is the introduction, by man, into the environment of substances or energy liable to cause hazards to human health (4). Pollution is the most serious of all environmental problems, posing a major threat to the health and wellbeing of people and animals (5). Water pollution occurs as a result of the presence of any objectionable or waste material capable of damaging the water quality (6). It has also been reported that all natural water sources contain one pollutant or another as a result of natural activities such as erosion, leaching and weathering along its course (6). Lack of hygienic water supply has been reported to be a cause of death of many young children in the Third World countries accounting for the death of more than two million children under the age of five years annually (7).

The effects of pollution were grouped into three main classes (8):

1. Clinical, which include alterations in the vital signs of temperature, pulse rate, blood pressure amongst others.

2. sub-clinical, such as damage to the immune system of the affected organisms and

3. Biochemical, such as impairment of enzyme functions, alterations in cell membrane and interference with some metabolic pathways.

Amilegbe River flows through Ilorin, a town in the North-central region of Nigeria, WestAfrica. Solid wastes are dumped (over the years) along the bank of the river by people living near and around the river bank. Due to these practices and the fact that people living along the bank of this river still depend on Amilegbe river water for most of their domestic activities, it has become necessary to assess the quality of this water and to determine the effect of its consumption on rat cellular system.

\section{MATERIALS AND METHODS}

\section{Chemicals and reagents}

P-nitrophenylphosphate (PNPP), NADH, 2, 4dinitrophenylhydrazine, pyruvate and other chemicals and reagents used in this study are of analytical grade, produced by British Drug House, Poole, England.

\section{Experimental animals and management}

Twenty weaning albino rats (Rattus novergicus) of average weight $32.5 \mathrm{~g} \pm 3.2$ were obtained from the Small Animal Holding Unit of the Department of Biochemistry, University of Ilorin, Ilorin, Nigeria. They were divided into two groups of ten rats each. The first group (Group A) was placed on bore-hole water as source of drinking water for eight weeks while the second group (Group B) was placed on Amilegbe river water as source of drinking water for eight weeks.

The experimental rats were maintained on commercial feeds ad libitum with water (Amilegbe river water or bore-hole water as the case may be) supplied. At the end of the experiment, the rats were sacrificed by anaesthetizing in a jar containing cotton wool soaked in diethylether. The jugular veins were cut and blood sample were collected first in heparinized bottles and then in stoppered plastic tubes. The latter was centrifuged to separate the serum (from whole blood) which was then labeled and stored frozen until required for analysis. The tissues of interest i.e. liver, kidney and small intestine were also removed, washed in ice-cold $0.25 \mathrm{Msucrose}$ solution, the kidneys were decapsulated and the tissues were homogenized in ice-cold $0.25 \mathrm{M}$ sucrose solution. Homogenized tissues were appropriately labeled and stored frozen until required for use.

\section{Experimental water}

The water sample was obtained from the Amilegbe side of the Asa River. The grab 
sample was collected by taking water from different points along the river course and then mixed in a plastic container to obtain a homogeneous mixture. The bore-hole water was obtained from a source about $500 \mathrm{~m}$ from the river.

\section{Physicochemical properties of the water samples}

The Amilegbe river water and bore-hole water were analyzed for their respective physicochemical properties according to standard methods (9). Heavy metal determination was done using the atomic absorption spectrophotometer (AAS). The physicochemical parameters determined include $\mathrm{pH}$, biochemical oxygen demand (BOD), chemical oxygen demand (COD), total solids (TS), total dissolved solids (TDS) and selected metals.

\section{Analysis of blood samples}

Haematological parameters of the blood samples collected were determined using standard clinical methods described (10).

Haemoglobin (Hb) concentration: In this method, $\mathrm{Hb}$ is converted to acid haematin by the action of $\mathrm{HCl}$.

Pack cell volume (PCV): Blood sample was centrifuged using a macrohaematocrit centrifuge at $10,000 \mathrm{xg}$ for 5 minutes.

\section{Enzyme and protein measurement}

$\begin{array}{llr}\text { Alkaline phosphatase (ALP) } & \text { (E.C.3.1.3.1): } \\ \text { The } & \text { method }\end{array}$ spectrophotometrically, the intensity of the yellow coloured complex formed from the reaction of $\mathrm{NaOH}$ with P-nitrophenol formed during the hydrolysis of PNPP by ALP.

Lactate dehydrogenase (LDH) (E.C.1.1.1.27): Enzyme activity was determined based on the method described by kubowitz and Otti (12). The method involves the reduction of pyruvate to lactate with the concomitant oxidation of $\mathrm{NADH}$ to $\mathrm{NAD}^{+}$. The method measures absorbance at $340 \mathrm{~nm}$.
Aspartate amino transaminase (AST) (E.C. 2.6.1.1) and Alanine amino transaminase (ALT) (2E.C.2.6.1.2): Specific activitie of these enzymes were determined using the method described by Reitman and Frenkel(13). The method measures spectrophotometrically the intensity of the red coloured hydrazone formed from the reaction of pyruvate with 2, 4dinitrophenylhydrazine at $546 \mathrm{~nm}$.

Protein concentration: This was determined by the biuret reaction described by Gornall et al (14). In this method, copper ion (blue) is made to react with the peptide bond of protein to give a purple coloured complex, the intensity of which was measured spectrophotometrically at $540 \mathrm{~nm}$.

\section{RESULTS}

Table 1 shows the physicochemical characteristics of both the Amilegbe river water and bore-hole water. Values for standard clean water as provided by WHO is also shown for comparative purposes. Relative to the WHO standard, bore-hole water is not polluted while Amilegbe river water could be described as being polluted relative to the control. Another evidence of pollution is the significantly high values of TS and TDS which are indicative of materials carried in suspension and solution $(\mathrm{p}<0.05)$. The TS and TDS of Amilegbe river water is 27 - and 26- folds respectively higher than values for the bore-hole water. There is also a considerable (significant, $\mathrm{p}<0.05$ ) increase in the BOD and COD values in the test water relative to control. Calcium and magnesium ion concentrations were significantly lower in the test water relative to control while the reverse was true for lead.

Figure 1 shows the body weight of rats maintained on Amilegbe river water and borehole water as their source of water over a period of eight weeks. Compared to the control there was significant increase in the body weight of rats maintained on Amilegbe river water $(\mathrm{p}<0.05)$. 
Table 1: Some physicochemical characteristics of Amilegbe water and bore-hole water Parameters

Amilegbe water

$(\mathrm{mg} / \mathrm{l})$

*pH $\quad 7.3$

Colour

BOD

COD

TS

TDS

Sulphate

Nitrate

Lead

Manganese

Calcium

Magnesium
Bore-hole water

$(\mathrm{mg} / \mathrm{l})$
${ }^{\wedge} \mathrm{WHO} \quad(\mathrm{mg} / \mathrm{l})$

RMC MPC

*Not in mg/l. RMC: Recommended maximum concentration; MPC: Maximum permissible concentration; ND: Not detected

${ }^{\wedge}$ Source: (15)

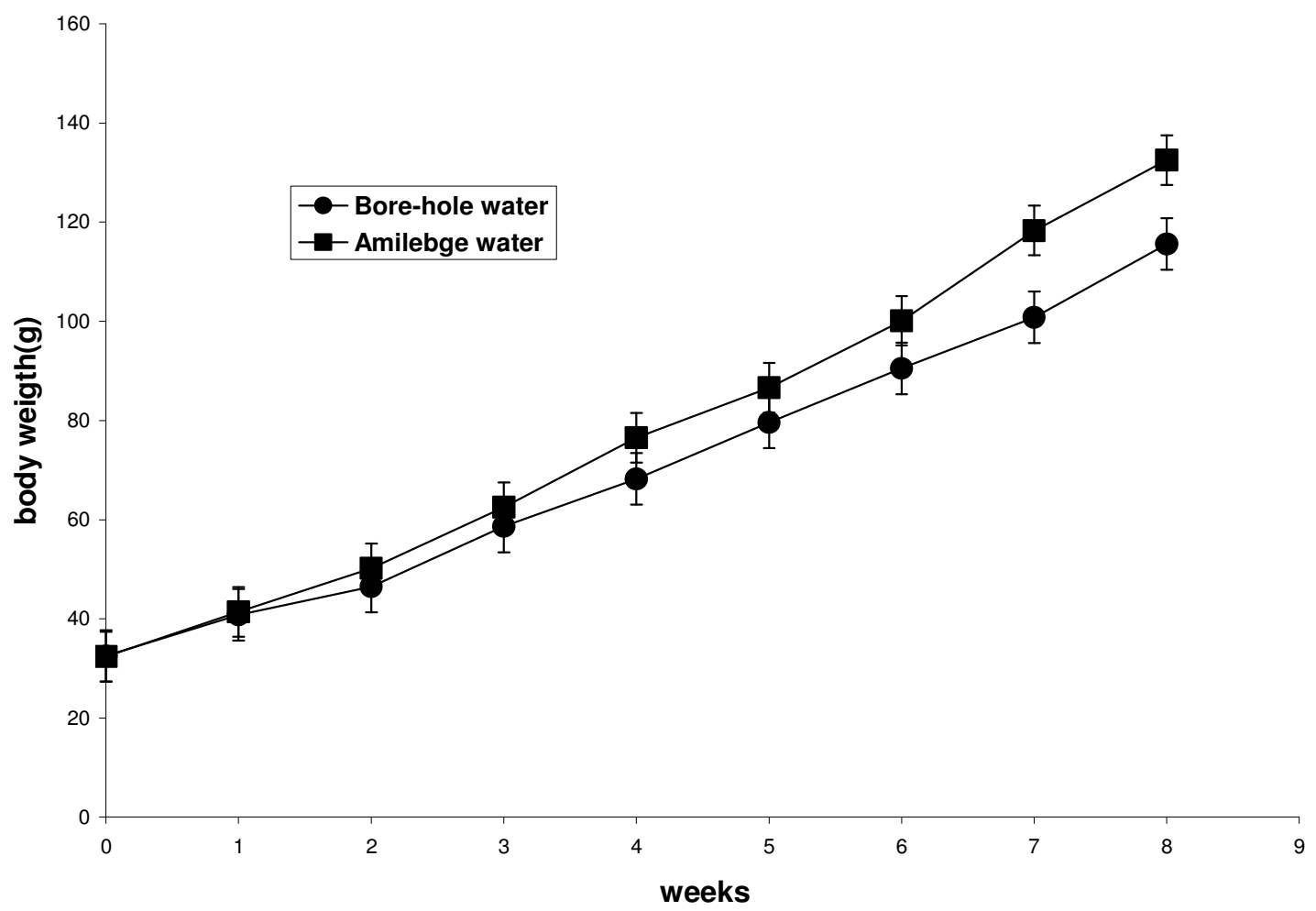

Figure 1: Body weight gain of rats placed on Amilegbe river water and borehole water. Plotted values are means of ten determinations \pm S.E.M.

Some haematological parameters of rats placed on Amilegbe river water and bore-hole water over a period of eight weeks is shown in Table
2. Relative to the control, the test rats exhibited significantly higher neutrophils and white blood cell (WBC) count as well as significantly lower 
Table 2: Comparison of some haematological parameters of rats maintained on Amilegbe water and bore-hole water

\begin{tabular}{lcc}
\hline Parameters & Control rats & Test rats \\
\hline PCV $(\%)$ & $43 \pm 5^{\mathrm{a}}$ & $40 \pm 5^{\mathrm{a}}$ \\
Neutrophil $(\%)$ & $16 \pm 2^{\mathrm{a}}$ & $28 \pm 3^{\mathrm{b}}$ \\
WBC $(/ \mathrm{L}) \times 10^{9}$ & $5.5 \pm 0.1^{\mathrm{a}}$ & $7.9 \pm 0.1^{\mathrm{b}}$ \\
Platelet $(/ \mathrm{L}) \times 10^{9}$ & $575 \pm 10^{\mathrm{a}}$ & $590 \pm 10^{\mathrm{a}}$ \\
$\mathrm{RBC}(/ \mathrm{L}) \times 10^{12}$ & $8.4 \pm 0.2^{\mathrm{a}}$ & $7.4 \pm 0.2^{\mathrm{b}}$ \\
$\mathrm{Hb}(\mathrm{g} / \mathrm{dl})$ & $15.5 \pm 0.4^{\mathrm{a}}$ & $13.9 \pm 0.4^{\mathrm{b}}$ \\
\hline Values are mean of ten determinations \pm S.E.M. \\
a,b Values along the same row with different \\
superscripts are significantly different $(p<0.05)$.
\end{tabular}

red blood cell $(\mathrm{RBC})$ and haemoglobin $(\mathrm{Hb})$ concentrations $(\mathrm{p}<0.05)$. The packed cell volume (PCV) of test rats was not significantly affected when compared with control $(\mathrm{p}<0.05)$.

Table 3 shows the specific activity of the enzymes studied (LDH, ALP, AST and ALT). There was significant reduction in LDH activity of the kidney and small intestine of the test rats relative to the control $(\mathrm{p}<0.05)$ while the liver LDH activity was not affected significantly $(p<0.05)$. However, serum LDH activity of rats placed on Amilegbe river water increased significantly relative to the control $(\mathrm{p}<0.05)$.

Also, ALP activity of rats maintained on Amilegbe river water was found to be significantly reduced in the kidney $(\mathrm{p}<0.05)$, liver and small intestine while serum ALP was not significantly affected $(\mathrm{p}<0.05)$.

The activities of the transaminases (AST \& ALT) of rat tissues and serum are also presented in Table 3. It is observed that there was significant reduction in both AST and ALT activities of the kidney, liver and small intestine of rats maintained on Amilegbe river water compared with control $(\mathrm{p}<0.05)$. Serum enzyme activity (AST and ALT) also increased significantly in Amilegbe river water treated rats compared with rats maintained on bore-hole water $(\mathrm{p}<0.05)$.

\section{DISCUSSION}

The high BOD and COD values are indicative of the presence of organic and inorganic pollutants respectively. It was reported that these parameters are responsible for odour and taste in water (15). $\mathrm{Mg}$ and $\mathrm{Ca}$ ions are essential minerals implicated in calcification and also serve as co-factors for a number of enzymes. From the nutritional point of view, Amilegbe river water may not be a good source of these minerals. The observed high concentration of lead in the test water (higher than the maximum permissible concentration recommended by WHO) may constitute a health risk to persons dependent on the water for their domestic activities. This is because lead has been reported to induce tissue damage leading to hypertension and some other cardiovascular diseases (16) and could also be neurotoxic (17).

Table 3: Effects of Amilegbe River water on the activities of some enzymes of selected tissues of rats.

\begin{tabular}{|c|c|c|c|c|c|}
\hline Treatment & Enzyme & Kidney & Small intestine & Liver & Serum \\
\hline Bore-hole Water (control) & \multirow{3}{*}{$\mathrm{LDH}$} & $20.5 \pm 0.3^{\mathrm{a}}$ & $28.2 \pm 0.5^{\mathrm{a}}$ & $15.8 \pm 0.2^{\mathrm{a}}$ & $5.4 \pm 0.1^{\mathrm{a}}$ \\
\hline & & & & & \\
\hline Amilegbe water & & $14.4 \pm 0.2^{\mathrm{b}}$ & $16.4 \pm 0.3^{\mathrm{b}}$ & $15.5 \pm 0.3^{\mathrm{a}}$ & $9.9 \pm 0.3^{b}$ \\
\hline Bore-hole water (control) & \multirow{3}{*}{ ALP } & $225 \pm 10^{\mathrm{a}}$ & $200 \pm 12^{\mathrm{a}}$ & $2.4 \pm 0.04^{\mathrm{a}}$ & $0.5 \pm 0.01^{\mathrm{a}}$ \\
\hline & & & & & \\
\hline Amilegbe water & & $150 \pm 7^{b}$ & $100 \pm 5^{b}$ & $1.8 \pm 0.03^{\mathrm{b}}$ & $0.6 \pm 0.02^{\mathrm{a}}$ \\
\hline Bore-hole water (control) & \multirow{3}{*}{$\mathrm{AST}$} & $13.2 \pm 2^{\mathrm{a}}$ & $200 \pm 12^{\mathrm{a}}$ & $23 \pm 2.4^{\mathrm{a}}$ & $2.5 \pm 0.5^{\mathrm{a}}$ \\
\hline & & & & & \\
\hline Amilegbe water & & $6.3 \pm 1.7^{\mathrm{b}}$ & $3.2 \pm 0.9^{b}$ & $17 \pm 1.9^{b}$ & $4.6 \pm 0.7^{b}$ \\
\hline Bore-hole water (control) & \multirow{3}{*}{ ALT } & $6.2 \pm 1.2^{\mathrm{a}}$ & $3.8 \pm 0.5^{\mathrm{a}}$ & $11.2 \pm 1.4^{\mathrm{a}}$ & $1.0 \pm 0.2^{\mathrm{a}}$ \\
\hline & & & & & \\
\hline Amilegbe water & & $1.0 \pm 0.2^{\mathrm{a}}$ & $2.4 \pm 0.3^{\mathrm{b}}$ & $2.4 \pm 0.3^{\mathrm{b}}$ & $1.6 \pm 0.1^{\mathrm{b}}$ \\
\hline
\end{tabular}


The higher body weight of rats maintained on Amilegbe river water may be due to the presence of some waste food materials deposited as domestic wastes along the river bank which might have contributed to the nutrient needs of the rats. This school or thought is supported by earlier study (18) which showed that Allium cepa grew better in an environment covered by polluted water than by tap water.

Neutrophils are matured leucocytes that control many biochemical infections. The observed increase in the concentration of neutrophils of the test rats may be due to the presence of pathogens in the polluted Amilegbe river water as reflected by the high BOD. This suggestion is supported by the significant increase in the white blood cell (WBC) count in test rats relative to the control rats $(\mathrm{p}<0.05)$. WBC fights against infections therefore the increase observed in the WBC of test rats may be as a result of infection arising from ingestion of polluted Amilegbe river water. The reduction observed for red blood cell (RBC) count and $\mathrm{Hb}$ concentration of test rats relative to the control may be due partly to the presence of heavy metals (lead) and other pollutants in Amilegbe river water. These pollutants may be lysing RBC. Destruction of $\mathrm{RBC}$ in fishes exposed to phenol pollution has earlier been reported (19). Previous study (20) reported reduced $\mathrm{RBC}$ in flounders exposed to heavy metal polluted water.

The observed reduction in LDH activity of kidney and small intestine of rats maintained on Amilegbe river water may be due to inhibition of the enzyme. This is because during the process of excretion and absorption (involving the kidney and small intestine respectively), the pollutant present in Amilegbe river water might have inhibited LDH activity. It had been reported (8) that impairment of enzyme functions is one of the effects of ingesting polluted water. The liver not being significantly affected by ingestion of Amilegbe river water may be due to its ability (by kupffer cells) to phagocytosize xenobiotics. The significantly higher serum LDH in Amilegbe river water treated rats may be due to leakage of enzyme (from kidney, small intestine or other tissues) into the serum since enzymes are known not to be of serum origin.
Reduction in ALP activity observed in all the rat tissues studied may be as a result of interactions between constituents of Amilegbe river water and the components of the membrane causing inhibition of the enzyme since ALP is a membrane bound enzyme. This suggestion is supported by the fact that serum ALP is not significantly affected by the treatment suggesting inhibition of the enzyme rather than leakage of enzymes from the cell into the extracellular space.

Reduction in AST and ALT activities of tissues of rats maintained on Amilegbe river water relative to the control implies that constituents of polluted Amilegbe river water may be inhibiting the enzymes or causing their leakages into the serum. Previous study (21) reported that elevated serum level of AST and ALT may be due to leakage of the enzymes from the liver and may significantly impair liver function. Another study (18) reported a reduction in activities of both AST and ALT of small intestine of fresh water bivalves exposed to heavy metal ions polluted water. Increased serum AST activity was reported in animals exposed to polluted water (22).This observation further support earlier suggestion that there is leakage of enzyme into the serum. Similarly, Kumar et al (23) reported that AST and ALT activities reduced in tissues of wistar rats treated with ammonia polluted water.

Conclusion: This study has proved that Amilegbe river water is indeed polluted. We have also been able to show that when rats are maintained on this water as their only source of water over a period of eight weeks, there was evidence of haematological changes affecting $\mathrm{RBC}$, WBC, neutrophils and even the $\mathrm{Hb}$ concentration. Enzyme studies also showed marked effect in tissues of rats maintained on this polluted water. The implication of these findings may be that people dependent on this water i.e. Amilegbe river water for domestic use including cooking, drinking and even washing may be exposed to some of these hazards.

\section{REFERENCES}

1.Oloyede, O.B.; Sunmonu, T.O.; Adeyemi, O. and Bakare, A.A. (2003) A biochemical 
assessment of the effect of polluted water from Asa River in rat kidney.Nigerian Journal of Biochemistry and Molecular Biology. 17.2532

\section{United Nations Environmental Programme} (UNEP) (1992) United Nations Conference on Environment and Development held at Rio de Janeiro, 3-14 June 1992.

3.NEST (1991) Human habitats in: Nigeria's threatened environmental study/Action (NEST) Publication, 228-240.

4.British Medical Association (BMA) (1991) Hazardous wastes and human health. In: Chemical Principles of Environmental Pollution by B.J. Alloway and C.D. Ayres, $2^{\text {nd }}$ edition. PP 10-24.

5.Holdgate, M.W. (1979) A perspective environmental pollution. In: Chemical Principles of Environmental Pollution by B.J. Alloway and D.C. Ayres, $2^{\text {nd }}$ edition.

6.FEPA (1991) Guidelines and standards for environmental control in Nigeria published by the Federal Environmental Protection Agency, Lagos. PP 15-34.

7.Professional Bulletin of the National Poison Centre, Malaysia (1998) The thirst for safe clean water. 18: 1-2.

8.Manahan (1991) In: Chemical principle of environmental pollution by Alloway and Ayres $2^{\text {nd }}$ edition. PP 64-98

9. APHA (1985) Standard methods for examination of water and waste water. American Public Health Association, $16^{\text {th }}$ edition, Washington. PP 100-909.

10. Khalaf-Allah, S.S. (1999) Effects of pesticides water pollution on some haematological, biochemical and immunological parameters in Tilapia nilotica. DTW-Dtsch-Tienarzti-Wochenschr. 106: $67-71$.
11. Wright, P.J., Leattwood, A.A. and Plummer, D.T. (1972) Enzymes in rat urine: Alkaline phosphatase. Enzymologia. 42:317-327.

12. Kubowitz, F. and Otti, P. (1943) Lactate dehydrogenase activity in urine. Biochem. $J$. 314: 94-96.

13. Reitman, S. and Frankel, S. (1957) A colourimetric method for the determination of serum GOT and GPT. Am.J.Clin.Petol. 28:56-63.

14. Gornall, A.G; Bardawill, C.T and David, M.M (1949) Determination of serum protein by means of biuret reaction. J.Biol.Chem. 177:751-766.

15. Lee, G.F. and Jones-Lee, A. (1993) Landfills and groundwater pollution issue. Dry tomb vs F/L wet cell landfills. Proc. Sardinian '93 IV National Landfill Symposium. S. Margherita dipula, Italy. PP $1-10$

16. Koop, S.J., Perry, H.M., Glonek, T., Elvanger, M., Perry, E., Barany, M. and Dargos, A.L. (1980) Cardiac physiologic metabolic changes after chronic low level of heavy metal feeding. Amer. J. Physiol. 239: 422-430.

17. Rose, J. (1983) Trace elements in health. A review of current issues. Butterworths, London. PP 24-35

18. Bakare, A.A; Mosuro, A.A. and Osibanjo, O. (1999) Cytotoxic effect of landfill leachate toxicity. Water Res. 17:1855-1861.

19. Wauga, D. (1966) Phenol induced changes in the peripheral blood of the bream (A bramibrama, L), Acta Hydrobiological. 8:87-95.

20. Halsband, E. and Halsband, I. (1963) Veranderingendes Blutbildes von Fishen infolge toxischer Schaden. Aduv fur fisheries Wissenschaft. 14:68-85. 
21. Schmidt, E. and Schmidt, F.W. (1963) Determination of serum GOT and GPT. Enzym.Biol.Clin. 3:1-3

22. Prat, N,; Toja, J.; Sola, C.; Burgos, M.D.; Plans, M. and Rieradevall, M. (1999) Effect of dumping and cleaning activities on the aquatic ecosystems of the Gaudiamar River following a toxic flood. Sci.Total Environ. 242: 1-3

23. Kumar, T.; Anitha, K.; Muralimohan, E.; Pillai, K.S.; Murthy, P.B.K. and SekarBabi, H. (1998) Toxicity of combination of a neem based pesticide and an organophosphorous pesticide to Wistar rat. J. Expt. India. 1:35-41. 